\title{
PENGARUH TERAPI KOGNITIF PERILAKUAN BERBASIS KEKUATAN TERHADAP PENINGKATAN RESILIENSI PADA REMAJA PANTI ASUHAN
}

\section{COGNITIVE BEHAVIORAL THERAPY EFFECTIVELY AND SIGNIFICANTLY IMPROVING RESILIENCE ON ADOLESCENCE ORPHANAGE}

\author{
Annisa Ridha Fadhillah \\ Qurotul Uyun \\ Indahria Sulistyarini \\ Program Studi Magister Psikologi Profesi (S2), Universitas Islam Indonesia, Yogyakarta \\ Email: dindarf@gmail.com
}

\begin{abstract}
This research is an experimental research aiming to understand whether strengths based cognitive behavioral therapy effectively improving resilience on adolescence orphanage. The subjects of this research were 15 adolescence orphanage from Sleman district who had a low to moderate level of resilience. Those 15 adolescence orphanage were divided into two groups, seven subjects from Orphanage $X$ as the experimental group and other subjects from orpahange $Y$ as the control group. The modules used for the training are based on four step of strengths based cognitive behavioral therapy of Padesky and Mooney (2012). This research used resilience scale adapted by researcher based on the original scale of resilience (Connor and Davidson, 2003). The data analysis of the research used independent sample $t$ test method. The result showed that the strengths based cognitive behavioral therapy is effective to improve adolescence orphanage resilience. Therefore the hypothesis isaccepted.
\end{abstract}

Key words: Strengths Based Cognitive Behavioral Therapy, Resilience, Adolescence Orphanage

\begin{abstract}
ABSTRAK
Penelitian ini merupakan penelitian kuasi eksperimen yang bertujuan untuk mengetahui apakah terapi kognitif perilakuan berbasis kekuatan efektif dalam meningkatkan resiliensi pada remaja panti asuhan. Subjek penelitian ini adalah 15 remaja panti asuhan di wilayah Kabupaten Sleman yang memiliki tingkat resiliensi rendah hingga sedang. Kelima belas remaja tersebut dibagi menjadi dua kelompok, yaitu 7 subjek dari Panti Asuhan X masuk dalam kelompok eksperimen dan 8 subjek dari Panti Asuhan Y masuk dalam kelompok kontrol. Modul yang digunakan dalam pelatihan ini didasarkan pada empat tahapan terapi kognitif perilakuan berbasis kekuatan dari Padesky dan Mooney (2012). Penelitian ini menggunakan satu skala sebagai alat pengukuran, yaitu skala resiliensi yang diadaptasi oleh peneliti berdasarkan skala asli resiliensi dari Connor dan Davidson (2003). Analisis data dari penelitian ini menunjukkan bahwa terapi kognitif perilakuan berbasis kekuatan terbukti efektif dalam meningkatkan resiliensi remaja panti asuhan. Dengan demikian hipotesis diterima.
\end{abstract}

Kata Kunci : Terapi Kognitif Perilakuan, Resiliensi, Remaja Panti Asuhan 
Perkembangan seorang anak tidak akan pernah terlepas dari asuhan orangtua, terutama orangtua kandung. Pentingnya keutuhan sebuah keluarga merupakan bekal bagi anak untuk mencapai masa depan yang baik. Akan tetapi, tidak semua anak, terutama di Indonesia, dapat hidup bersama dengan kedua orangtua dan keluarganya. Banyak anak yang harus terpisah dari kedua orangtuanya karena berbagai alasan, antara lain masalah ekono$\mathrm{mi}$, orangtua yang sudah tiada atau konflik antara kedua orangtua sehingga rentan untuk diserahkan ke panti asuhan.

Kehidupan di panti asuhan akan sangat berbeda dengan kehidupan bersama keluarga yang utuh. Yildirim (Gursoy dkk, 2012) mengungkapkan bahwa kondisi fisik di panti asuhan, kurangnya tenaga kerja, pandangan masyarakat terhadap panti asuhan, kurangnya dukungan keluarga bagi anak dapat memberikan efek yang negatif terhadap anak di panti asuhan. Anak atau remaja yang tinggal di panti asuhan memiliki permasalahan yang lebih besar pada aspek sosial dan emosional dibandingkan dengan remaja lain yang tinggal bersama kedua orangtuanya. Penelitian-penelitian menunjukkan bahwa orangtua yang mengekspresikan emosi positif, penerimaan dan dukungan, penghiburan di saat susah, akan berhubungan dengan kemampuan anak untuk mengelola emosi dengan cara yang positif (Santrock, 2007). Akan tetapi, kesempatan ini tidak diperoleh bagi anak panti asuhan karena mereka telah berpisah dan jarang melakukan kontak dengan orang tua.

Secara ideal, remaja yang berada di panti asuhan dapat mengembangkan kemampuan kognitif, emosional, dan sosial dengan baik seperti remaja pada umumnya. Pada masa remaja, perkembangan kognitif mengalami peningkatan sehingga remaja dapat berpikir lebih abstrak, logis, dan idealis (Santrock, 2007). Aspek sosial dan emosional juga dapat berkembang serta dilatih dengan baik oleh remaja panti asuhan karena mereka selalu melakukan kontak sosial dengan remaja lain di panti tersebut. Kondisi ideal yang seharusnya dimiliki oleh remaja panti asuhan tersebut bertentangan dengan hasil wawancara pada remaja panti asuhan di mana remaja tersebut menunjukkan rendahnya kemampuan personal sehingga dalam menghadapi masa sulit. Sebagai contoh, EA tidak dapat meminta bantuan kepada orang di sekitarnya. Kemampuan untuk bertahan serta bangkit dari masa sulit tersebut dalam psikologi dinamakan resiliensi.

\section{Resilensi}

Resiliensi dikarakteristikkan sebagai kemampuan untuk bangkit kembali dari masa sulit, untuk bertahan di bawah stres yang cukup menekan, dan tetap gigih terlepas dari stres yang berkelanjutan atau bahkan pada peristiwa yang di luar ekspektasi (Meichenbaum, 2011). Grotberg 
(1995) mengungkapkan bahwa terdapat tiga karakteristik seseorang yang resilien yaitu (1) dukungan eksternal dan sumber daya, (2) internal dan kekuatan personal, dan (3) sosial dan kemampuan interpersonal. Berdasarkan pemaparan tentang resiliensi tersebut, dapat diketahui bahwa EA tidak menunjukkan ketiga karakteristik individu yang resilien. EA tidak memiliki kemampuan personal, seperti self-esteem dan self- efficacy untuk menghadapi masa sulit.

Connor dan Davidson (2003) menyebutkan resiliensi sebagai kemampuan untuk berkembang dalam menghadapi masa sulit. Grotberg (1999) secara sederhana mengartikan resilensi sebagai kapasitas manusia untuk menghadapi, menjalani, bertambah kuat, atau bahkan bertransformasi dari mengalami masa sulit. Sedangkan Richardson dkk (1990) mendefinisikan resiliensi sebagai proses mengatasi masalah hidup yang mengganggu, menimbulkan stres, atau menantang dengan cara yang menyebabkan seseorang memiliki kemampuan untuk melindungi diri dan menyelesaikan masalah daripada larut dalam masalah tersebut. Meichenbaum (2011) menjelaskan bahwa resiliensi dikarakteristikkan sebagai kemampuan untuk bangkit kembali dari mengalami masa sulit, bertahan dalam situasi stres yang menekan serta gigih terlepas dari stres yang berkelanjutan dan bahkan saat suatu hal tidak sesuai dengan ekspetasi.
Surgenor (2013) menunjukkan bahwa resiliensi yang rendah akan membawa individu kepada self-esteem yang rendah, indikasi untuk bunuh diri, dan depresi. Sebaliknya, resiliensi yang tinggi pada diri individu akan dapat berasosiasi pada hasil yang positif dalam berbagai area seperti kesehatan fisik, perilaku yang sehat, performansi dalam edukasi, pekerjaan, penghasilan dan penurunan pada tindak kriminal (Friedli \& Parsonage, dalam Geldard, 2009). Individu seperti remaja panti asuhan merupakan individu yang rentan mengalami resiliensi yang rendah dikarenakan kurangnya faktor protektif seperti dukungan orangtua, terutama saat remaja tersebut sedang menghadapi masalah. Grenberg (2006) melaporkan bahwa resiliensi berhubungan dengan penggunaan yang efektif pada kemampuan kognitif dalam menghadapi stres. Individu yang resilien dalam menghadapi masa sulit akan menggunakan kemampuan kognitifnya dengan efektif. Hal ini bertolak belakang dengan individu yang tidak resilien, di mana mereka tidak dapat menggunakan kemampuan kognitifnya secara efektif sehingga individu tersebut tidak mampu menemukan solusi bagi permasalahannya. Individu yang tidak resilien kurang menyadari adanya kekuatan tersebut sehingga terapi kognitif perilakuan cocok untuk diterapkan. Terapi ini mengedepankan perubahan pemikiran yang maladaptif ke pemikiran yang adap- 
tif, sehingga mereka dapat menemukan kekuatan dalam dirinya dan dapat berperilaku yang lebih adaptif seperti mencoba untuk mencari pemecahan terkait masalah yang dihadapi.

Connor dan Davidson (2003) mengungkapkan bahwa terdapat lima aspek dalam resiliensi pada diri seseorang. Pertama: Kompetensi personal, standar yang tinggi pada diri seseorang, dan keuletan. Kompetensi ini memberikan kekuatan dan kepatuhan terhadapsebuah tujuan ketika berhadapan pada situasi di mana seorang individu harus mengulang kembali pada garis awal. Kedua: Kepercayaan pada naluri toleransi pada pengaruh negatif dan memperkuat efek dari stres. Aspek ini berfokus pada ketenangan, keputusan, dan ketepatan dalam menghadapi stres. Ketiga: Penerimaan positif pada perubahan dan hubungan yang aman dengan orang lain. Aspek ini terutama berkaitan pada kemampuan adaptasi seseorang. Keempat: Kontrol, yang diaplikasikan dalam mencapai suatu tujuan dan kemampuan untuk mencari bantuan dari orang lain (social support). Kelima: Pengaruh spiritualitas, dinilai dari kepercayaan terhadap Tuhan dan nasib.

Selanjutnya, Hermann dkk (2011) menyebutkan tiga faktor yang menyebabkan resiliensi dalam diri seseorang. Pertama: Faktor personal. Ciri kepribadian (keterbukaan, extraversion, dan agreeableness), internal locus of control, penguasaan diri, self-efficacy, self-esteem, penilaian kognitif (interpretasi positif pada suatu peristiwa dan mengintegrasikan masalah secara kohesif ke dalam selfnarrative), dan optimis secara terbukti berkontribusi padaresiliensi. Kedua: Faktor biologi. Lingkungan pada masa awal kehidupan yang keras dapat menyebabkan dampak pada perkembangan struktur otak, fungsi dan sistem neurobiologikal. Perubahan dapat terjadi pada ukuran otak, sistem saraf, sensifitas reseptor, sintesis, dan reuptake neurotransmitters. Perubahan fisikal pada otak ini secara substansial akan mengurangi kerentanan pada perkembangan psikopatologi. Ketiga: Dalam level microenvironmental, dukungan sosial, termasuk hubungan dengan keluarga dan teman sebaya, berkorelasi dengan resiliensi

\section{Terapi Kognitif Perilakuan Berbasis Kekuatan}

Terapi kognitif perilakuan berbasis kekuatan adalah terapi yang menggunakan berbagai kemampuan dalam diri individu sebagai dasar untuk membangun sebuah pondasi resiliensi (Padesky \& Mooney, 2012). Fokus terapi kognitif perilakuan berbasis kekuatan adalah untuk mengkonstruksi keyakinan dan perilaku yang resilien daripada membongkar keyakinan dan perilaku yang menghalangi seseorang untuk menjadi resilien (Padesky \& Mooney, 2000). Pendekatan berbasis 
kekuatan (strength based), yang merupakan dasar dari terapi ini, memiliki perspektif bahwa seseorang dilihat sebagai individu yang mampu dan memiliki kekuatan yang bersumber dari dalam dirinya dan lingkungan sosial (Bannink, 2013). Bannink juga menyebutkan bahwa pendekatan ini mengajak klien untuk mendeskripsikan masa depan yang mereka harapkan dan mencari solusi untuk mencapai hal tersebut. Terdapat beberapa penyesuaian dari terapi kognitif perilakuan klasik untuk mendukung pengembangan resiliensi pada klien yaitu fokus pada kekuatan klien saat ini, penggunaan konstruktif dari citra (imagery), dan metafora yang dihasilkan klien (client-generated metaphors).

Empat tahap model terapi kognitif perilakuan berbasis kekuatan menurut Padesky dan Mooney (2012) adalah berikut ini. Pertama: Pencarian pada kekuatan personal. Kekuatan personal akan diidentifikasi dari kehidupan klien sehari-hari. Kekuatan personal inilah yang akan menjadi dasar untuk membangun sebuah model resiliensi individu. Kedua: Mengkonstruksi model resiliensi. Kekuatan-kekuatan tersembunyi pada individu yang sudah teridentifikasi akan menjadi dasar untuk membangun sebuah model resiliensi yang memiliki bentuk berupa strategistrategi praktis. Ketiga: Mengaplikasi model resiliensi. Model resiliensi yang telah dibangun kemudian akan diaplikasikan pada situasi-situasi lain yang dianggap individu sebagai situasi yang sulit. Keempat: Mempraktekkan model resiliensi. Eksperi-men resilien diciptakan untuk menguji kualitas dan kegunaan dari resilien.

Padesky dan Mooney (2012) dalam penelitiannya mengkonstruksi sebuah model terapi kognitif perilakuan berbasis kekuatan (strengths based) yang dikhususkan untuk mengembangkan atribut positif pada individu yaitu resiliensi. Fokus terapi kognitif perilakuan berbasis kekuatan adalah untuk mengkonstruksi keyakinan dan perilaku yang resilien daripada membongkar keyakinan dan perilaku yang menghalangi seseorang untuk menjadi resilien.

Terapi kognitif perilakuan berbasis kekuatan merupakan terapi yang tepat diberikan kepada remaja panti asuhan untuk meningkatkan resiliensi. Meningkatnya resiliensi pada remaja panti asuhan dapat memberikan keuntungan yaitu remaja tersebut akan dapat menghadapi serta bangkit kembali dari masa sulit yang tengah dilalui.

Hipotesis dalam penelitian ini adalah terdapat perbedaan resiliensi antara kelompok yang diberi perlakuan (kelompok eksperimen) dan kelompok yang tidak diberi perlakuan (kelompok kontrol). Resiliensi pada kelompok eksperimen lebih meningkat jika dibandingkan dengan kelompok kontrol. 


\section{METODE PENELITIAN}

\section{Rancangan Penelitian}

Rancangan penelitian ini adalah kuasi eksperimen, yakni sebuah rancangan eksperimen yang memiliki perlakuan, pengukuran dampak, unit eksperimen namun tidak menggunakan penugasan acak untuk menciptakan perbandingan dalam rangka menyimpulkan perubahan yang disebabkan perlakuan (Cook \& Campbell, 1979).

\section{Tabel 1. Desain Penelitian}

\begin{tabular}{lllll}
\hline Kelompok & Prates & Perlakuan & Pascates & Tindak Lanjut \\
\hline KE & Y1 & X & Y2 & Y3 \\
KK & Y & $-X$ & Y2 & Y3 \\
\hline
\end{tabular}

Keterangan:

$\mathrm{KE}=$ Kelompok Eksperimen

$\mathrm{KK}=$ Kelompok Kontrol

$\mathrm{Y} 1$ = Prates

$\mathrm{X}=$ Perlakuan

$-\mathrm{X}=$ Waiting list

$\mathrm{Y} 2=$ Pascates

$\mathrm{Y} 3$ = Tindak lanjut

\section{Subjek Penelitian}

Subjek dari penelitian ini adalah remaja panti asuhan berusia 12-18 tahun, memiliki jenjang pendidikan minimal sedang menempuh SMP, minimal telah tinggal di panti asuhan selama 1 tahun, dan memiliki tingkat resiliensi dalam kategori sedang dan rendah.

\section{Metode Pengumpulan Data}

Metode pengumpulan data dalam penelitian ini berupa skala yang berisi butir-butir pernyataan yang akan dijawab oleh subjek penelitian. Skala yang digunakan dalam penelitian ini adalah skala resiliensi. Skala resiliensi awalnya berjumlah 25 aitem favorable. Setelah diujicobakan, 4 aitem dinyatakan gugur (kurang dari batas kritis 0,25). Hasil korelasi antar aitem berkisar antara 0,086 sampai 0,727 dengan nilai reliabilitas alpha cronbach sebesar 0,894.

\section{Prosedur Intervensi}

Prosedur penelitian meliputi tiga langkah. Pertama: Persiapan penelitian. Peneliti mendapatkan surat izin penelitian dari Fakultas Psikologi dan Ilmu Sosial Budaya Universitas Islam Indonesia untuk disampaikan kepada pihak terkait. Kedua: 
Penyusunan rancangan penelitian dan pembuatan modul. Intervensi yang digunakan berupa terapi kognitif perilakuan berbasis kekuatan. Terapi ini bertujuan untuk meningkatkan resiliensi pada remaja panti asuhan dengan menyadari kekuatan-kekuatan tersembunyi yang sudah ada dalam diri masing-masingsubjek. Ketiga: Penyusunan alat ukur dan uji coba alat ukur. Penelitian ini menggunakan alat ukur berupa skala resiliensi yang terdiri dari 25 aitem (sebelum uji coba). Penyusunan skala resiliensi ini diadaptasi dari skala asli yang dibuat oleh Connor dan Davidson (2003).

Teknik Analisis Data
Analisis data yang digunakan berupa statistik dengan teknik analisis Independent Sample t-test pada gained score dengan bantuan program SPSS 20.00 for windows.

\section{HASIL PENELITIAN}

\section{Deskripsi Data Penelitian}

Data dalam penelitian ini mendeskripsikan 15 subjek penelitian yang terdiri atas 7 subjek kelompok eksperimen dan 8 subjek kelompok kontrol. Kelompok eksperimen terdiri dari 7 orang perempuan. Sedangkan kelompok kontrol terdiri dari 4 orang lakilaki dan 4 orangperempuan.

Tabel 2. Deskripsi resiliensi antara prates-pascates-tindak lanjut

\begin{tabular}{ccccccccc}
\hline \multirow{2}{*}{ Pengukuran } & \multicolumn{3}{c}{ Kelompok Eksperimen } & \multicolumn{5}{c}{ KelompokKontrol } \\
\cline { 2 - 9 } & Min & Maks & Rerata & SD & Min & Maks & Rerata & SD \\
\hline Prates & 38 & 57 & 49 & 7,18 & 45 & 63 & 63 & 6,98 \\
Pascates & 47 & 76 & 63 & 10,29 & 45 & 59 & 53,12 & 5,59 \\
Tindak lanjut & 55 & 81 & 65,14 & 10,09 & 43 & 61 & 52,12 & 6,37 \\
\hline
\end{tabular}

Deskripsi data skor prates, pascates, dan tindak lanjut pada kelompok eksperimen menunjukkan peningkatan rerata skor resiliensi sebesar 14 (prates $=49$ dan pascates $=63$ ). Hal ini menunjukkan bahwa subjek yang diberi intervensi berupa terapi kognitif perilakuan berbasis kekuatan memperoleh skor resiliensi yang lebih tinggi pada saat prates jika dibandingkan dengan subjek yang tidak diberi intervensi. Pada kelompok kontrol menunjuk- kan penurunan rerata skor resiliensi sebesar 9,88 (prates $=63$ dan pascates $=$ 53,12 ). Hal ini menunjukkan bahwa kelompok kontrol yang tidak mendapatkan intervensi mengalami penurunan skor resiliensi.

\section{Hasil Uji Asumsi}

Uji normalitas menggunakan tehnik Kolmogorof-Smirnov menunjukkan $\mathrm{p}>$ 0,05 yang berarti sebaran data pada prates 
dan pascates dinyatakan normal. Uji homogenitas Levene's test menunjukkan $p>0,05$, artinya sebaran data kelompok

\section{PEMBAHASAN}

Penelitian ini bertujuan untuk mengetahui pengaruh terapi kognitif perilakuan berbasis kekuatan terhadap peningkatan resiliensi pada remaja panti asuhan. Berdasarkan analisis data yang telah dilakukan diperoleh hasil bahwa terapi kognitif perilakuan berbasis kekuatan berpengaruh terhadap peningkatan resiliensi para remaja panti asuhan. Berdasarkan penjabaran tersebut, diketahui bahwa hipotesis penelitian yang berbunyi terdapat perbedaan resiliensi antarakelompok yang diberi perlakuan (kelompok eskperimen) dan kelompok yang tidak diberi perlakuan (kelompok kontrol), dapat diterima. Berdasarkan hasil uji hipotesis di atas, dapat disimpulkan bahwa terdapat perubahan resiliensi dari sebelum perlakuan (prates) dan setelah perlakuan (pascates) begitu pula hasil dari prates ke masa tindak lanjut. Perubahan tersebut menunjukkan bahwa terdapat perbedaan resiliensi pada remaja panti asuhan setelah diberikan terapi kognitif perilakuan berbasis kekuatan.

Hasil penelitian menunjukkan bahwa terdapat peningkatan resiliensi pada subjek setelah melalui tahap-tahap pada terapi kognitif perilakuan berbasis ke- mampuan. Terapi ini memiliki keyakinan dasar bahwa setiap orang telah memiliki pondasi untuk membangun sebuah atribut positif (Padesky \& Mooney, 2012) sehingga salah satu tahap dalam terapi yaitu pencarian kekuatan (search for strengths) merupakan bagian penting dalam peningkatan resiliensi. Sama hal nya dengan pencarian distorsi kognitif (cognitive distortion) pada terapi kognitif perilakuan klasik, tahapan pencarian kekuatan dalam kegiatan sehari-hari ini juga merupakan upaya untuk membawa kekuatan-kekuatan yang tidak disadari dalam diri seseorang ke kesadaran. Dengan mencari kekuatan-kekuatan tersebut, individu dapat menyadari kekuatan yang sudah ia miliki dan selanjutnya dapat membangun sebuah model resiliensi.

Tahap konstruksi model resiliensi merupakan tujuan utama dari terapi ini karena dengan model tersebut individu menjadi mudah untuk mengingat siapa dirinya dan apa kekuatan yang ia miliki saat menghadapi masa sulit. Konstruksi model resiliensi dilakukan dengan pembayangan serta metafora yang menjadi faktor terapeutik pada terapi ini. Pembayangan (imagery) lebih memberikan dampak yang lebih pada emosi daripada sekedar kata-kata (Hackmann, BennetLevy, 2011; Holmes \& Mathews, 2010). Saat seseorang membayangkan peristiwa positif, pembayangan tersebut akan terhubung dengan emosi yang lebih positif 
daripada memikirkan peristiwa yang positif dengan menggunakan kata-kata (Holmes, Lang, \& Shah, 2009). Emosi yang positif secara empiris akan terhubung dengan meningkatnya sumber-sumber emosional seperti kesejahteraan hidup dan resiliensi (Fredrickson, 2001). Dengan menemukan pembayangan yang positif mengenai dirinya, secara tidak langsung subjek akan terhubung dengan emosi positif yang dapat mengarah pada meningkatnya resiliensi. Subjek yang masih berusia remaja akan mengalami kesulitan jika pembayangan yang telah ditemukan tersebut hanya ditulis dalam lembar kerja. Oleh karena itu, dilakukan kegiatan menggambar hasil pembayangan tersebut agar pembayangan tersebut dapat lebih dipahami dan diingat oleh subjek.

Tahapan dalam terapi ini tidak akan memberikan hasil yang maksimal jika tidak digunakan secara langsung dalam kehidupan nyata. Oleh karena itu, praktek resiliensi atau jadwal kegiatan (schedule acticity) diberikan pada tahap akhir sebagai media bagi subjek untuk dapat mempraktekkan hal yang telah diterima selama sesi terapi sebelumnya. Tahap ini merupakan eksperimen perilaku untuk menguji kegunaan model resiliensi yang di mana lebih memberikan kontribusi dalam meningkatkan resiliensi daripada mengevaluasi keyakinan-keyakinan negatif (Padesky \& Mooney, 2012).

Selama proses terapi, interaksi anta- ra terapis dan subjek merupakan salah satu faktor terapeutik dalam meningkatnya resiliensi pada subjek. Terapis dalam terapi ini akan lebih banyak tersenyum untuk mendorong kreativitas subjek dan memberikan tanda bahwa suatu hal yang positif dan inspiratif akan sangat dihargai oleh terapis (Padesky \& Mooney, 2012). Selain itu, terapis berfokus pada apa yang ingin subjek ubah daripada mengeksplorasi masalah, dan apa yang sudah benar di dalam diri subjek daripada apa yang salah (Bannink, 2013). Terapis juga akan lebih banyak berbicara dengan nada yang menyenangkan, mendengarkan dengan seksama, dan menerima halhal yang diutarakan subjek tanpa bertanya secara detail (Bannink,2013).

\section{SIMPULAN DAN SARAN}

\section{Simpulan}

Berdasarkan hasil analisis data dan pembahasan yang telah dilakukan, maka dapat disimpulkan bahwa ada pengaruh terapi kognitif perilakuan berbasis kemampuan untuk meningkatkan resiliensi pada remaja panti asuhan.

\section{Saran}

Pertama: saran bagi penelitian selanjutnya. Peneliti selanjutnya dapat menggunakan jumlah subjek yang lebih sedikit untuk meningkatkan interaksi antara terapis dan subjek. Selain itu, modul 
intervensi dapat dimodifikasi untuk lebih difokuskan pada pencarian karakteristik personal dan pemberian umpan balik positif sebelum pelaksanaan tugas rumah. Subjek dalam penelitian ini dapat lebih terbuka kepada sesama teman sehingga tidak merasa malu untuk bercerita ataupun meminta pertolongan saat menghadapi sebuah masalah. Subjek penelitian juga diharapkan untuk dapat menerapkan pengetahuan, informasi, ide dan saran dari hasil terapi ini ataupun dari subjek lainnya dalam kehidupan sehari-hari.

\section{DAFTAR PUSTAKA}

Bannink, F.P. (2013). Are you ready for positive cognitive behavioral therapy. The Journal of Happiness and Well Being, 1(20), 61-69

Connor, K.M., \& Davidson, R.T. (2003). Development of a new resilience scale: the connor-davidson resilience scale (CD-RISC). Research Article: Depression and Anxiety, 18, 76-82.

Fredrickson, B.L. (2001). The role of positive emotions in positive psychology: the broaden and build theory of positive emotions. The American Psychologist, 56(3), 218226.

Geldard, K. (2009). Practical interventions for young people at risk. London: Sage Publication.
Gursoy, F., Bicakci, M.Y., Orhan, E., Bakirci, S., Catak, S., \& Yerebakan, O. (2012). Study on slef concept levels of adolescents in the age group of 13-18 who live in Orphanage and those do not live in Orphanage. International Journal of Social Sciences and Education, 2(1), 56-66.

Grenberg, M.T. (2006). Promoting resilience in children and youth: preventive interventions and their interface with neurosience. Annuals of The New York Academy of Sciences, 1094(1), 139-50.

Grotberg, E.H. (1995). A guide to promoting resilience in children: strengthening the human spirit. Early Childhood Development: Practise and Reflections.

Grotberg, E.H. (1999). Taping your inner strength: how to find the resilience to deal with anything. Oakland, CA: New Harbinger Publications, Inc.

Hackmann, A., Bennett-Levy, J., \& Holmes, E. (2011). Oxford guide to imagery in cognitive therapy. Oxford: Oxford UniversityPress.

Hermann, H., Stewart, D.E., GranadosDiaz, N., Berger, E.L., Jackson, B., \& Yuen, T. (2011). What is resilience. The Canadian Journal of Psychiatry, 56(5).

Holmes, E.A., Lang, T.J., \& hah, D.M. (2009). Developing interpretation 
bias modification as a cognitive vaccine for depressed mood imgning positive events make you feel better than thinking about them verbally. Journal of Abnormal Psychology, 118(1), 76-88.

Meichenbaum, D. (2011). Resiliency building as a means to prevent PTSD and related adjustment problems in military personnel. In B.A. Moore \& W.F. Penk (Eds.), Treating PTSD in Military Personnel: A Clinical Handbook. New York: Guilford Press.

Padesky, C.A., \& Mooney, K.A. (2000). Applying client creativity to recurrent problems: constructing possibilities and tolerating doub. Journal of Cognitive Psychotherapy: An International Quarterly, 14(2), 149-161.
Padesky, C.A., \& Mooney, K.A. (2012). Strengths-based cognitive therapy: a four-step to build resilience. Journal of Clinical Psychology and Psychotherapy, 19, 283-290.

Richardson, G.E., Neiger, B.L., Jenson, s., \& Kumpfer, K.L. (1990). The resilience model, Health Education, 21(6), 33-39.

Santrock, J.W. (2007). Perkembangan masa hidup: edisi kelima. Jakarta: Penerbit Erlangga.

Surgenor, P.W.G. (2013). Recovery \& resilience: gender differences in suicide intervention treatment at Pieta House, Paper presenteed at the 27th World of The International Association for Suicide Prevention. 


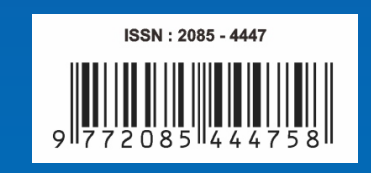

